University of Nebraska - Lincoln

DigitalCommons@University of Nebraska - Lincoln

\title{
Dominant species constrain effects of species diversity on temporal variability in biomass production of tallgrass prairie
}

\author{
H. Wayne Polley \\ USDA, wayne.polley@ars.usda.gov \\ Brian J. Wilsey \\ lowa State University \\ Justin D. Derner \\ USDA-ARS, Justin.Derner@ars.usda.gov
}

Follow this and additional works at: https://digitalcommons.unl.edu/usdaarsfacpub

Part of the Agricultural Science Commons

\footnotetext{
Polley, H. Wayne; Wilsey, Brian J.; and Derner, Justin D., "Dominant species constrain effects of species diversity on temporal variability in biomass production of tallgrass prairie" (2007). Publications from USDA-ARS / UNL Faculty. 446.

https://digitalcommons.unl.edu/usdaarsfacpub/446
}

This Article is brought to you for free and open access by the U.S. Department of Agriculture: Agricultural Research Service, Lincoln, Nebraska at DigitalCommons@University of Nebraska - Lincoln. It has been accepted for inclusion in Publications from USDA-ARS / UNL Faculty by an authorized administrator of DigitalCommons@University of Nebraska - Lincoln. 


\title{
Dominant species constrain effects of species diversity on temporal variability in biomass production of tallgrass prairie
}

\author{
H. Wayne Polley, Brian J. Wilsey and Justin D. Derner
}

H.W. Polley (wpolley@spa.ars.usda.gov), Grassland, Soil and Water Research Laboratory, US Dept of Agriculture, Agricultural Research Service, 808 East Blackland Road, Temple, TX 76502, USA. - B. J. Wilsey, Dept of Ecology, Evolution and Organismal Biology, Iowa State Univ., Ames, IA 50012, USA. - J. D. Derner, High Plains Grasslands Research Station, US Dept of Agriculture, Agricultural Research Service, Cheyenne, WY 82009, USA.

\begin{abstract}
Species diversity is thought to stabilize functioning of plant communities. An alternative view is that stability depends more on dynamics of dominant species than on diversity. We compared inter-annual variability (inverse of stability) of aboveground biomass in paired restored and remnant tallgrass prairies at two locations in central Texas, USA. Data from these two locations were used to test the hypothesis that greater richness and evenness in remnant than restored prairies would reduce variability in aboveground biomass in response to natural variation in rainfall. Restored prairies were chosen to be similar to paired remnant prairies in characteristics other than species diversity that affect temporal variability in biomass. Variability was measured as the coefficient of variation among years (square root of variance/mean; $\mathrm{CV}$ ), where variance in community biomass equals the sum of variances of individual plant species plus the summed covariances between species pairs. Species diversity over five years was greater by a factor of 2 or more in remnant than restored prairies because richness and evenness were greater in remnant than restored prairies. Still, the CV of community biomass during spring and $\mathrm{CV}$ of annual biomass production did not differ consistently between prairie types. Neither the sum of species covariances nor total community biomass differed between prairies. Biomass varied relatively little in restored compared to remnant prairies because biomass of the dominant species in restored prairies (the grass Schizachyrium scoparium) varied less than did biomass of other dominant and sub-dominant species. In these grasslands, biomass response to natural variation in precipitation depended as much on characteristics of a dominant grass as on differences in diversity.
\end{abstract}

Increased biodiversity may reduce the amount by which aggregate properties of plant communities vary through time (McNaughton 1985, Dodd et al. 1994, Tilman et al. 2006). Variability in an aggregate property, like biomass production of plant communities $\left(\mathrm{B}_{\mathrm{c}}\right)$, typically is calculated using the coefficient of variation (CV). As applied to community biomass, the $\mathrm{CV}$ equals the square root of the variance of $B_{c}$ divided by mean $B_{c}$. Variance of $B_{c}$, in turn, can be calculated by adding the sum of the variances of biomass for individual plant species to the summed covariances between species pairs (Doak et al. 1998). Biodiversity and its components, species richness and species evenness (equitability of species abundances), thus may reduce temporal variability of community biomass by increasing community biomass or by reducing summed variances or covariances of biomass (Tilman 1996).

Richness effects on variability derive largely from the differential responses of species to environmental fluctuations (Cottingham et al. 2001). When fluctuations of individual species are asynchronous, summing across species fluctuations reduces variance in community properties compared to variance of the average species. The greater the number of species considered, the greater is the statistical probability that fluctuations of individual species will average out and that summed variances will be smaller than variance of the average species (portfolio effect; Doak et al. 1998). As richness and the probability that species will respond differently to changes increase (McNaughton 1977), the sum of 
species covariances also should decrease (Tilman 1999, Cottingham et al. 2001).

Evenness influences variability largely by regulating the richness effect. Most species in natural communities contribute little to community biomass and other properties. When evenness is low, species make such unequal contributions to biomass that the addition or loss of minor species has little effect on summed variances (portfolio effect) and the sum of covariances between species is determined mostly by covariances between dominant species.

Effects of both richness and evenness on expression of the portfolio effect depend on how variances of individual species scale with mean biomass (Tilman 1999) and on whether biomass varies more or less in dominant species than in other species (Lepš 2004). The more variance increases per unit of increase in mean biomass, the greater will be the decline in summed variances as richness and evenness increase.

We measured aboveground biomass and plant species diversity and its components (richness, evenness) for five years in replicated plots within paired restored and remnant tallgrass prairies at two locations in the Blackland Prairie region of central Texas, USA. We sought to determine whether differences in diversity between communities subject to natural assembly processes affected stability of biomass production. Most recent diversity studies have utilized experimentally assembled plant mixtures. The assembly process itself has been suggested to influence results from such studies (Huston 1997), although it has been argued that random assembly of experimental communities mimics species losses and additions in some ecosystems and eliminates the influence of factors that may covary with diversity in nature (Schmid et al. 2002). Remnants of the original Blackland Prairie are rare, and typically are of small area ( $<10$ ha, Diamond and Smeins 1993). Restorations of tallgrass prairie are even more uncommon. Especially rare are restorations like those included in this study that were vegetated with seeds collected from the paired remnant prairie and that share a common group of dominant perennial grasses with remnants. Remnant and restored prairies at each location studied are managed similarly, but both species richness and species evenness were greater in remnant than restored grasslands during the first year of measurement (2001; Polley et al. 2005). With data collected over five years, we tested the hypothesis that inter-annual variability in biomass would be reduced in each remnant prairie compared to the paired restored prairie because of greater species richness and evenness. Our alternative hypothesis was that diversity effects on temporal variability in biomass would be constrained by traits of dominant species (Wardle et al. 1997, Grime 1998, Lepš 2004, Polley et al. 2006).

\section{Methods}

\section{Site characteristics and sampling}

Paired remnant and restored tallgrass prairies are located at two sites, near Riesel $\left(31^{\circ} 28^{\prime} \mathrm{N}, 96^{\circ} 55^{\prime} \mathrm{W}\right)$ and Temple $\left(31^{\circ} 05^{\prime} \mathrm{N}, 97^{\circ} 20^{\prime} \mathrm{W}\right)$, in central Texas, USA. Soils at study sites are vertisols with clay content $>50 \%$. Annual precipitation averages $896 \mathrm{~mm}$ at the Riesel site (41-years mean) and $879 \mathrm{~mm}$ at the Temple site (89-years mean) with peaks in spring and autumn.

Restored prairies were paired with nearby remnant prairies in an effort to control for characteristics other than species diversity, including soil type, management, and dominant species, that affect temporal variability in biomass. At each site, tallgrass prairie was restored by applying 'seed-hay' collected from the remnant prairie to a previously-cultivated field in which maize was grown. Restored prairies are located within eight kilometers of remnant prairies at each site and were seeded 9 (Riesel) and 20 (Temple) years prior to sampling. Prairies at each site are managed similarly (hayed or burned) and are not grazed by domestic livestock. Exotic species, defined as species that originated outside the continental United States, were few in both remnant and restored prairies and contributed $<6 \%$ of aboveground biomass (Polley et al. 2005). Restored and remnant prairies are 0.5 and 1.6 ha (Riesel) and 9.8 and 4.6 ha (Temple) in size, respectively. We did not conduct chemical or physical analyses of soils, but note that $\mathrm{N}$ mineralization rates have been related to the size of the particulate organic matter pool in soil (Parry et al. 2000). Prairie restoration has increased the amount of particulate organic carbon (POC) in the surface $5 \mathrm{~cm}$ of soil, although the POC pool remains smaller on the restored than remnant prairies we studied (Potter and Derner 2006).

Prior to sampling, we randomly-located 12 points in each prairie. Each point served as the center of a circular plot of $5 \mathrm{~m}$ radius $\left(78.5 \mathrm{~m}^{2}\right)$ from which samples were taken. In June and November of each year from 2001 through 2005, we clipped aboveground biomass to $2 \mathrm{~cm}$ height in one randomly-located area $(0.71 \times$ $0.71 \mathrm{~m} ; 0.5 \mathrm{~m}^{2}$ ) in each of the 12 circular plots in each prairie. Different $0.5 \mathrm{~m}^{2}$ areas were sampled in each circular plot each season and year. Sampling was timed to correspond with periods of peak biomass for early-season (June) and late-season species in these prairies (November). June is the month during which richness among actively growing species usually is maximal, so we separated live (green) tissue removed from plots in June by species. June also is the month during which remnant prairies in this area typically are hayed, so any effect of diversity on early-season production is of practical importance. Plant tissue harvested during November of each year was separated 
by photosynthetic type $\left[\mathrm{C}_{4}\right.$ (mostly perennial grasses) and $\mathrm{C}_{3}$ (mostly perennial forbs)]. Harvested tissues were dried to constant mass at $60^{\circ} \mathrm{C}$ and weighed. Aboveground production each year was estimated for each plot by summing values of peak biomass of photosynthetic types.

\section{Calculation of plant species diversity and variances}

For each of the 12 plots in each prairie, we calculated plant species diversity present in June of each year using the reciprocal of Simpson's index, $\frac{1}{\sum_{\mathrm{i}=1}^{\mathrm{s}} \mathrm{Pi}^{2}}$, where $\mathrm{P}_{\mathrm{i}}$ is the proportion of biomass contributed by species i to total aboveground biomass and $S$ is the total number of species present in June (species richness; Table 1). Simpson's index integrates measures of species richness per unit of area and species evenness. Evenness was calculated by dividing the reciprocal of Simpson's index by richness. Unlike the measure of evenness derived from the frequently-used Shannon index of diversity, evenness calculated from Simpson's index is mathematically-independent of richness (Smith and Wilson 1996).

Samples from any one year may underestimate contributions of minor or infrequent species to biomass production over multiple years, so we calculated species diversity and its components using the five-year (20012005) average of green biomass of each species harvested from each circular plot and from all plots per prairie in June. For each of the 12 circular plots in each prairie and for each prairie (data combined from all plots), we also fit an exponential equation to the relationship between the mean relative abundance of each species over five years in June and the rank order of each species (n) from 1 for the most abundant species to $\mathrm{n}$ for the least abundant species (for data from all plots, $\mathrm{r}^{2}$ ranged from 0.88 to $\left.0.99 ; \mathrm{p}<0.0001\right)$. The exponential coefficient of these rank-abundance relationships (b) equals the slope of the negative relationship between the natural logarithm of relative

Table 1. Summary of variables calculated with data collected from 12 plots in each of two remnant prairies and restored prairies. Variables were calculated using data from each plot (Plot) or data combined from the 12 plots in each prairie (Prairie). Variables were calculated with data collected each year (Annual) or with data combined over the five years of the experiment (five years).

\begin{tabular}{lll}
\hline Variable & \multicolumn{1}{c}{ Plot } & Prairie \\
\hline Aboveground biomass & Annual & - \\
Species diversity & Annual; 5 years & 5 years \\
Rank-abundance relationship & 5 years & 5 years \\
Mean-variance relationship & 5 years & 5 years \\
Variability in biomass & 5 years & 5 years \\
\hline
\end{tabular}

abundance and rank and thus is an index of how equitably biomass is distributed among species (Wilsey and Polley 2004). Larger (less negative) values of the exponential coefficient indicate a more equitable distribution of biomass among species.

Diversity effects on expression of the portfolio effect depend on how variances in biomass of individual species $\left(\delta^{2}\right)$ scale with mean biomass $(\mathrm{m})$, as described by Taylor's power function (Taylor 1961),

$\delta^{2}=\mathrm{cm}^{\mathrm{z}}$

where $\mathrm{c}$ is a constant and $\mathrm{z}$ is a scaling coefficient. Logarithmic transformation of this equation produces a linear mean-variance function in which $\mathrm{z}$ equals the slope of the positive relationship between the logarithm of $\delta^{2}$ and the $\operatorname{logarithm}$ of $\mathrm{m}\left[\log \left(\delta^{2}\right)=\mathrm{c}+\mathrm{z} \times \log (\mathrm{m})\right]$. For each of the 12 circular plots in each prairie, we fit a linear regression to the relationship between the logarithm of $\delta^{2}$ in biomass of each species over five years and the logarithm of mean biomass. The slope of this regression is an estimate of the value of the scaling coefficient ( $\mathrm{z})$.

Variance in community biomass equals the sum of variances of individual plant species plus the summed covariances between species pairs. We calculated variances of June biomass for each species for each circular plot and for all plots combined in each prairie. Summed covariances were calculated for each plot and each prairie as the difference between the variance of community biomass and the sum of species variances. Prairies were dominated by relatively few species, so the sum of species covariances depended mainly on covariances among dominants. In order to assess effects of dominant species on covariances, we calculated covariance in biomass for all possible pairs of the four most abundant species in each prairie.

Variability in aboveground biomass present in June and in annual biomass production were calculated as both the coefficient of variation in biomass (CV; standard deviation/mean) and standard deviation of $\log$-transformed values of biomass $(\mathrm{SD}[\log$ (biomass) $])$. The $S D[\log$ (biomass) $]$ is considered the preferable metric when the distribution of biomass values is highly skewed (McArdle et al. 1990).

\section{Statistical analyses}

Annual measurements of aboveground biomass production and of aboveground biomass and species diversity in June were analyzed with a repeated measures analysis of variance (ANOVA). Effects of location and prairie type (remnant, restored) on the value of $b$ from rankabundance relationships and evenness calculated using average biomass per species in June during the five years of sampling were analyzed with ANOVA. Location and 
prairie type were considered fixed effects because all known remnant and paired restored prairies from the area were included in this analysis. Linear and exponential regressions were fit using Sigma Plot 2000 (SPSS). Regression slopes between log (variance) and $\log$ (mean biomass) were compared with the F statistic (Weisberg 1980). We also used regression to test for relationships between plot-scale measurements of biomass variability and diversity.

For the 2-4 most productive (dominant) species in each prairie, we tested for equality between the observed $\mathrm{CV}$ of biomass and the $\mathrm{CV}$ of biomass calculated for each plot using the variance-mean relationship developed across species. We used paired t-tests to determine for each dominant species whether the mean of differences between observed and calculated values of CV differed significantly from zero (Sokal and Rohlf 1981).

\section{Results}

\section{Species composition and diversity}

The perennial $\mathrm{C}_{4}$ grass little bluestem Schizachyrium scoparium was the most abundant species in remnant and restored prairies at Riesel and in the remnant prairie at Temple (Table 2). Schizachyrium contributed $55 \%$ of aboveground biomass in the restored prairie at Riesel, but only about $20 \%$ of biomass in other prairies. Perennial $\mathrm{C}_{4}$ grasses were the subdominant species in restored prairies at both Temple ( $S$. scoparium and indian grass Sorghastrum nutans) and Riesel (S. nutans). In contrast, perennial forbs, including Illinois bundle- flower Desmanthus illinoensis, prairie-plantain Arnoglossum (formerly Cacalia) plantagineum and Maximilian sunflower Helianthus maximiliani, and the $\mathrm{C}_{3}$ grass Canada wildrye Elymus canadensis were subdominants in remnant prairies. As is typical of natural vegetation in many areas, biomass production was dominated by relatively few species. The two most abundant species in restored prairies (both $\mathrm{C}_{4}$ grasses) contributed $>45 \%$ of mean biomass in June, for example. For each prairie, the four most abundant species accounted for 41 to $82 \%$ of June biomass.

Species diversity and richness (S) in June were greater across years and locations in remnant than restored prairies (mean diversity $=4.2$ and $2.8 ; \mathrm{p}=$ 0.001 and mean richness $=11.0$ and 7.4 species per $0.5 \mathrm{~m}^{2}$ plot; $\mathrm{p}=0.005$ in remnant and restored prairies, respectively, $n=48$ ). Species evenness $(E)$ in June did not differ consistently across years between prairie types or locations at the plot scale (mean $=0.41$ and 0.39 for remnant prairies at Temple and Riesel and 0.45 and 0.32 for restored prairies at Temple and Riesel; $\mathrm{p}=$ 0.017 for the location $\times$ prairie type interaction in a repeated measures ANOVA with location and prairie type as fixed effects). Evenness based on mean biomass per plot over five years was greater and the exponential coefficient of rank-abundance relationships (b) was less negative, on average, for remnant than restored prairies $(\mathrm{E}=0.28$ and $0.23 ; \quad b=-0.40$ and -0.84 for remnant and restored prairies). Consequently, biomass generally was more equitably-distributed among species in remnant than restored grasslands, but differences in $\mathrm{E}$ and rank-abundance relationships between prairie types varied with location $(p<0.03$ for the location $\times$ prairie type interaction). Evenness over five years was

Table 2. Mean values of the percentage contribution of the most productive (dominant) species to aboveground biomass in spring (June) and of the coefficient of variation in biomass across the 10-12 plots per prairie in which dominant species occurred (CV) for remnant and restored tallgrass prairies at two locations (Temple, Riesel). The expected value of CV was derived using the variancemean relationship developed across species in each prairie. Paired t-tests were used to determine whether the mean of differences between observed and expected values of $\mathrm{CV}$ differed significantly from zero.

\begin{tabular}{|c|c|c|c|c|c|c|}
\hline Prairie/species & $\%$ of biomass & Observed CV & Expected CV & $\mathrm{n}$ & t-value & p-value \\
\hline \multicolumn{7}{|l|}{ Temple restored } \\
\hline Panicum virgatum & 25.4 & 1.40 & 1.41 & 12 & -0.05 & 0.96 \\
\hline Schizachyrium scoparium & 22.4 & 0.96 & 1.28 & 12 & -3.40 & 0.006 \\
\hline Sorghastrum nutans & 10.7 & 0.82 & 1.42 & 12 & -5.46 & 0.0002 \\
\hline \multicolumn{7}{|l|}{ Temple remnant } \\
\hline Schizachyrium scoparium & 19.2 & 0.79 & 1.25 & 12 & -5.81 & 0.0001 \\
\hline Helianthus maximiliani & 9.3 & 1.78 & 1.56 & 11 & 1.64 & 0.13 \\
\hline Elymus canadensis & 6.4 & 1.60 & 1.51 & 10 & 0.79 & 0.45 \\
\hline \multicolumn{7}{|l|}{ Riesel restored } \\
\hline Schizachyrium scoparium & 55.2 & 0.37 & 0.83 & 12 & -8.39 & $<0.0001$ \\
\hline Sorghastrum nutans & 19.7 & 0.96 & 1.01 & 12 & -0.76 & 0.46 \\
\hline \multicolumn{7}{|l|}{ Riesel remnant } \\
\hline Schizachyrium scoparium & 18.8 & 0.86 & 1.07 & 12 & -2.39 & 0.04 \\
\hline Desmanthus illinoensis & 16.8 & 1.34 & 1.16 & 11 & 0.82 & 0.43 \\
\hline Arnoglossum plantagineum & 14.4 & 0.91 & 1.11 & 12 & -1.58 & 0.14 \\
\hline Sorghastrum nutans & 10.6 & 1.36 & 1.16 & 12 & 1.54 & 0.15 \\
\hline
\end{tabular}


Table 3. Plant species diversity and its components (richness, evenness) in remnant and restored prairies at two locations (Temple, Riesel) in central Texas, USA. Diversity indices and the exponential coefficient of rank-abundance relationships (b; greater values indicate a more equitable distribution of biomass among species) were calculated using data combined from 12 plots per prairie over five years.

\begin{tabular}{|c|c|c|c|c|}
\hline & \multicolumn{2}{|c|}{ Temple } & \multicolumn{2}{|c|}{ Riesel } \\
\hline & Remnant & Restored & Remnant & Restored \\
\hline Species diversity & 14.12 & 7.29 & 9.15 & 2.87 \\
\hline Species richness & 69 & 46 & 57 & 48 \\
\hline Species evenness & 0.20 & 0.16 & 0.16 & 0.06 \\
\hline Rank-abundance coefficient & -0.18 & -0.39 & -0.23 & -1.07 \\
\hline
\end{tabular}

greater in plots in the remnant than restored prairie at Riesel (mean $=0.27$ and 0.15 , respectively; $\mathrm{n}=12$ ), but did not differ significantly between prairie types at Temple (mean $=0.29$ and 0.30 for remnant and restored prairies, respectively).

Diversity followed a similar trend when calculated at the prairie scale. Species diversity over five years was greater by a factor of 2 or more in remnant than restored prairies (paired t-test, $\mathrm{p}=0.03$; Table 3 ). The species pool in restored prairies was largely a subset of that of the paired remnant prairie. Of the 46 and 48 species encountered in restored prairies at Temple and Riesel, respectively, only four and nine species that contributed a mean of $2.4 \%$ and $1.8 \%$ to biomass over five years were not observed in the paired remnant prairie.

\section{Biomass and biomass variability}

Biomass varied among years (Fig. 1) partly in response to inter-annual variation in precipitation. Aboveground biomass in June and annual biomass production at Riesel were linearly correlated with precipitation summed from near the end of the previous growing season (November) through May and October, respectively, of the year in which biomass was measured (Fig. 2). We found no correlation between biomass of Temple prairies and precipitation measured at the
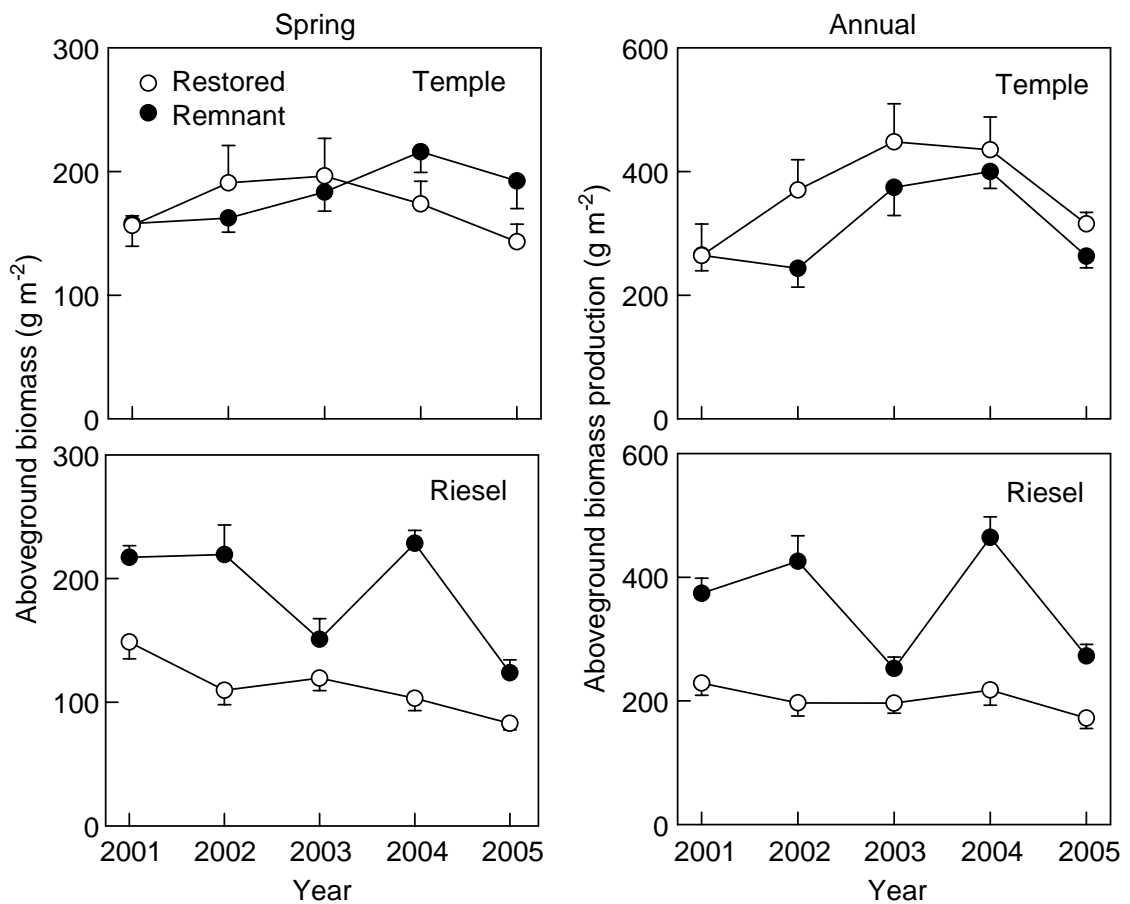

Fig. 1. Aboveground green biomass in spring (June, left panels) and annual aboveground biomass production (right panels) of remnant and restored tallgrass prairies at two locations (Temple, Riesel) during the years of 2001 through 2005. Bars indicate 1 $\mathrm{SE}$ of the mean $(\mathrm{n}=12)$. Note that the scale of the $\mathrm{y}$-axis differs between left and right panels. 


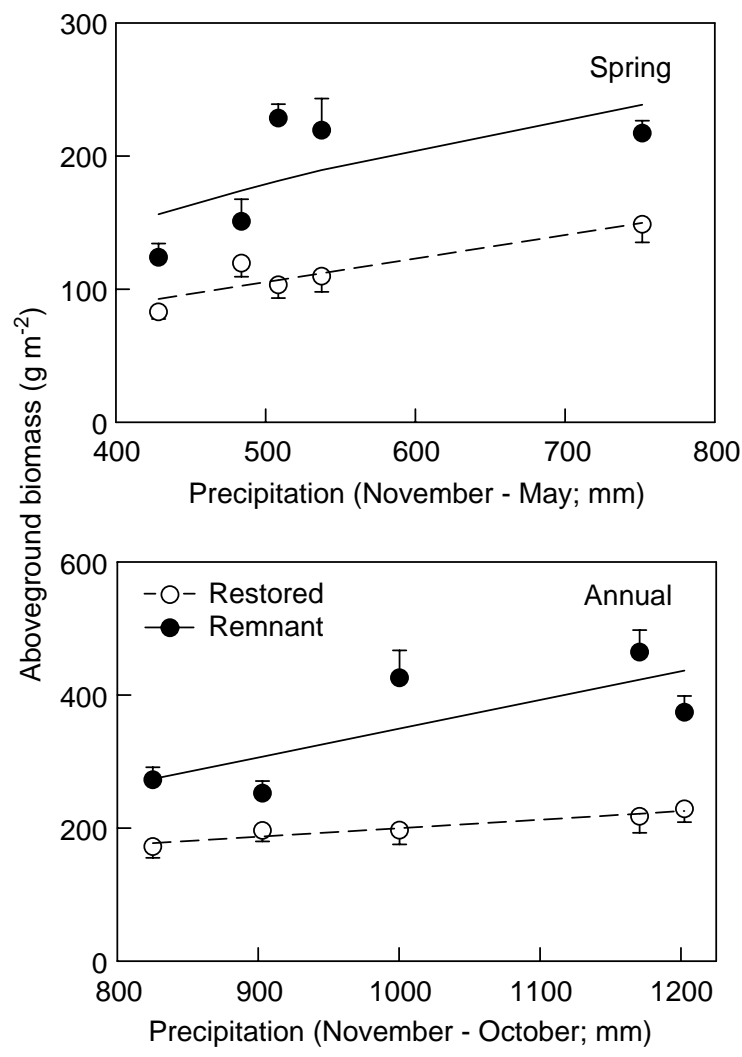

Fig. 2. Relationship of aboveground green biomass in spring (June, upper panel) and annual aboveground biomass production (lower panel) of remnant and restored tallgrass prairies at Riesel (2001 through 2005) to precipitation. Lines are regression fits to data from the restored prairie (aboveground biomass $=16.73+0.18 \times p p t, r^{2}=0.77, p=0.03$; annual biomass production $=71.75+0.13 \times \mathrm{ppt}, \mathrm{r}^{2}=0.90$, $\mathrm{p}=0.009$ ) and remnant prairie (aboveground biomass $=$ $-731.36+146.46 \times \ln (\mathrm{ppt}), \quad \mathrm{r}^{2}=0.23, \quad \mathrm{p}=0.23 ; \quad$ annual biomass production $=-82.69+0.43 \times \mathrm{ppt}, \mathrm{r}^{2}=0.44, \mathrm{p}=$ $0.13)$. Bars indicate $1 \mathrm{SE}$ of the mean $(\mathrm{n}=12)$. Precipitation averages $530 \mathrm{~mm}$ and $896 \mathrm{~mm}$ for the November through May and November through October periods, respectively (41-years mean).

nearest meteorological station located $>8 \mathrm{~km}$ from prairies.

Neither aboveground biomass in June nor the total of aboveground production each year (annual production) differed consistently between prairie types or locations during the five years of measurements (repeated measures ANOVA; Fig. 1). Effects of both prairie type and location on June biomass differed among years $(\mathrm{p}<0.004)$. Differences in annual production between prairie types varied between locations and among years $(\mathrm{p}<0.0001)$.

Despite greater diversity in remnant than restored prairies, neither of the indices of biomass variability we used [CV of aboveground biomass; SD of $\log$ (bio- mass)] differed between prairie types $(p>0.55)$ or locations $(\mathrm{p}>0.14)$ when calculated with data from June harvests $(\mathrm{n}=24$ plots; Table 4). Surprisingly, annual biomass production at Riesel varied more among years in the remnant prairie than in the lessdiverse restored prairie $[p=0.04$ for the location $\times$ prairie type interaction for $\mathrm{SD}$ of $\log$ (biomass) in two-way ANOVA].

Neither index of biomass variability was correlated with diversity or its components when data from all plots and prairies were analyzed with regression $(p>$ $0.11, \mathrm{n}=48$ plots). Within a given prairie type, however, there was evidence that diversity affected variability. Greater E reduced biomass variability in plots of remnant prairies (CV of biomass $=54.9$ $84.8 \times E, r^{2}=0.27, p=0.006, n=24$ plots $)$. Variability did not depend on $S(\mathrm{p}=0.25, \mathrm{n}=24$; range 1735 species plot $\left.^{-1}\right)$. Biomass variability of restored prairies actually increased with greater $\mathrm{S}(\mathrm{CV}$ of biomass $=2.1+1.7 \times S, \quad r^{2}=0.15, \quad p=0.03, \quad n=24$ plots; range 14-27 species plot $^{-1}$ ), but was not correlated with either diversity or E ( $p>0.78)$.

Neither the sum of species covariances nor the sum of species variances differed between prairie types. Summed covariances were negative on average in June for all prairies at the plot scale (mean $=-568$ and -909 for remnant and restored prairies, respectively; $\mathrm{p}=0.27, \mathrm{n}=24)$. Summed variances did not differ consistently between prairie types whether calculated at the plot scale (mean $=1870$ and 1363 for remnant and restored prairies; $\mathrm{p}=0.28, \mathrm{n}=24$ ) or prairie scale $($ mean $=41578$ and 44378 for remnant and restored prairies; $\mathrm{n}=2$ ). The diversity effect on summed variances ultimately depends on how variances of individual species scale with mean biomass $(\mathrm{z})$. Values of $\mathrm{z}$, calculated as slopes of linear regressions of $\log$ (variance) on log (mean biomass over five years), did not differ significantly among the 12 plots in each of the four prairies $(p>0.05)$. To compare mean-variance relationships between locations and prairie types, therefore, we fit a single regression to the relationship of log (variance) to log (mean biomass) across plots at each location (Fig. 3) and for each prairie type. Variance increased more per unit of increase in mean biomass in prairies at Temple than Riesel $(\mathrm{z}=1.77$ and 1.72, respectively; $\left.\mathrm{F}_{(2,1021)}=25.6, \mathrm{p}<0.001\right)$, but variancemean relationships did not differ significantly between remnant and restored prairies $\left(\mathrm{F}_{(2,1021)}=0.4\right.$, $\mathrm{p}>0.50)$.

\section{Influences of species dominance on biomass variability}

Summed variances in species biomass did not differ between remnant and restored prairies because biomass 
Table 4. Mean values (standard deviation, SD) of variability in aboveground biomass over five years in remnant and restored tallgrass prairies at two locations (Temple, Riesel). Two metrics of variability were calculated for each of 12 plots in each prairie [coefficient of variation, CV of biomass; SD of log-transformed values of biomass, SD of log(biomass)] using both biomass harvested in June each year and annual biomass production. Values within a row $(n=12)$ differed significantly if followed by different letters.

\begin{tabular}{|c|c|c|c|c|}
\hline & \multicolumn{2}{|c|}{ Temple } & \multicolumn{2}{|c|}{ Riesel } \\
\hline & Remnant & Restored & Remnant & Restored \\
\hline \multicolumn{5}{|l|}{ Spring } \\
\hline $\mathrm{CV}$ of biomass & $28.21(10.87)$ & $32.04(15.32)$ & 34.45 (11.65) & $34.89(10.73)$ \\
\hline SD of log (biomass) & $0.133(0.066)$ & $0.138(0.064)$ & $0.167(0.063)$ & $0.156(0.048)$ \\
\hline \multicolumn{5}{|l|}{ Annual } \\
\hline $\mathrm{CV}$ of biomass & $35.94(11.83)$ & $37.62(8.68)$ & $35.80(8.82)$ & $27.63(10.38)$ \\
\hline SD of log (biomass) & $0.153(0.046) \mathrm{a}$ & $0.171(0.040) \mathrm{a}$ & $0.157(0.042) \mathrm{a}$ & $0.121(0.046) b$ \\
\hline
\end{tabular}

varied less for the dominant species in restored prairies than for other abundant species. For each prairie, the observed CV of biomass for S. scoparium was smaller

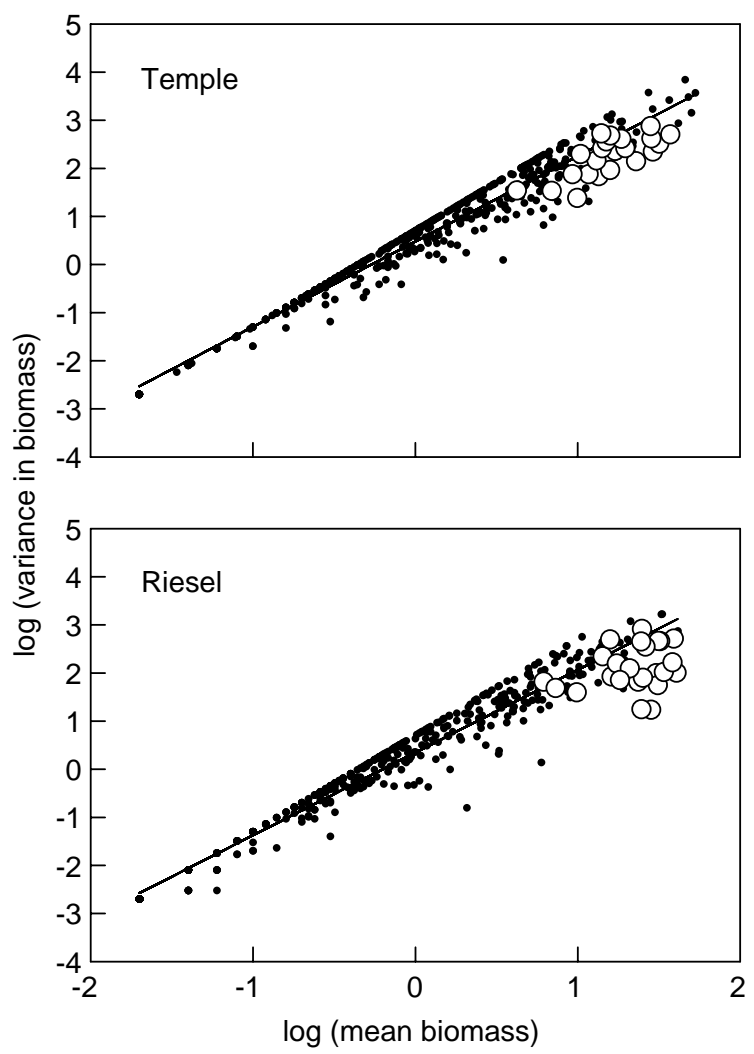

Fig. 3. Relationship between the logarithm of variance in aboveground biomass over five years and the logarithm of mean biomass per $0.5 \mathrm{~m}^{2}$ sampling area for each species in each of 12 plots in remnant and restored tallgrass prairies at Temple and Riesel. Data for the dominant species in prairies, the $\mathrm{C}_{4}$ grass Schizachyrium scoparium, are indicated with enlarged open circles. Lines are linear regression fits to data from Riesel $\left[\log (\right.$ variance $)=0.35+1.72 \times \log ($ biomass $), \mathrm{r}^{2}=$ $0.96, \mathrm{p}<0.0001, \mathrm{n}=524]$ and Temple $[\log ($ variance $)=$ $0.48+1.77 \times \log$ (biomass) $\left., \mathrm{r}^{2}=0.96, \mathrm{p}<0.0001, \mathrm{n}=501\right]$. than the $\mathrm{CV}$ of biomass calculated for this species assuming variance scaled with biomass as indicated by the variance-mean relationship developed using all species (Table 2). The CV of the $\mathrm{C}_{4}$ grass $S$. nutans varied less than predicted in the restored prairie at Temple $(\mathrm{p}=0.0002, \mathrm{n}=12)$, but observed and predicted values of the $\mathrm{CV}$ of $S$. nutans biomass did not differ significantly in either prairie at Riesel $(p>0.15)$. For other dominant and sub-dominant species, including switchgrass Panicum virgatum, $H$. maximiliani, $D$. illinoensis, E. canadensis and A. plantagineum, the observed $\mathrm{CV}$ did not differ from the CV calculated using the overall variance-mean relationship in each prairie. The variance-mean scaling coefficient $(\mathrm{z})$ was greater than 1 in all prairies. If $\mathrm{z}$ had remained constant across species, the greater diversity in remnant than restored prairies would have reduced summed variances. The diversity effect was not realized because biomass varied less for the species (S. scoparium) that dominated restored prairies than for other species.

Summed covariances were significantly more negative at Temple than Riesel $(\mathrm{p}=0.0008, \mathrm{n}=24$; means $=-1294$ and -183 , respectively) largely because of the dynamics of two dominant species at Temple that were minor components of Riesel prairies. The sum of covariances for all possible pairs of the four most abundant species in Temple prairies was highly negative when calculated at the prairie scale $(-95496$ and -13079 for restored and remnant prairies, respectively). For the restored prairie at Temple, covariance between the $\mathrm{C}_{4}$ grasses Panicum virgatum and Schizachyrium scoparium alone was more negative $(-100249)$ than covariances summed among the four most abundant species ( -95496$)$. Biomass of the $\mathrm{C}_{3}$ grass Elymus canadensis apparently responded differently to environmental fluctuations than other dominants in the remnant prairie at Temple, for covariance between E. canadensis and each of the other three dominant species considered ( $S$. scoparium, Helianthus maximiliani, Mimosa roemeriana) was negative (range from 6650 to -12 747). Summed covariances among 
dominant species was less negative or even positive at the prairie scale for Riesel ( 5415 and -10588 for restored and remnant prairies, respectively), where $P$. virgatum and $E$. canadensis each comprised $<2.5 \%$ of biomass.

\section{Discussion}

We measured inter-annual variability (inverse of stability) of aboveground biomass in paired restored and remnant tallgrass prairies to test the prediction that variability in biomass would decline as species diversity increased. Species richness (S) and evenness (E) were greater in remnant than restored prairies. Nevertheless, variability in community biomass (CV of biomass) did not differ between prairie types. Surprisingly, annual biomass production at one location actually varied more among years in the remnant than the less-diverse restored prairie. Neither the sum of species covariances (indicative of the outcome of species interactions) nor relationships between variances in biomass and mean biomass developed using all species differed between prairie types. Rather, variability in community biomass differed little between remnant and restored prairies because biomass of the dominant species ( $S$. scoparium) in restored prairies varied less than did biomass of other dominant and sub-dominant species in more-diverse remnant prairies.

Species E and S likely differed sufficiently between the remnant and restored prairies we studied to have affected biomass variability. When the exponent of variance-relative abundance scaling relationships ( $\mathrm{z}$ ) is $>1$, as in these prairies, variance in species biomass increases with mean abundance. The larger is the value of $\mathrm{z}$, the greater is the proportional disparity in variance between species of high and low abundance. When $\mathrm{z}>1$ and is similar among species, increasing $\mathrm{E}$ or $\mathrm{S}$ generally reduces the sum of species variances by reducing maximum abundances. As reported here and noted in another grassland study (Lepš 2004), however, variance-mean and variance-relative abundance relationships may differ among species. The effect of diversity on community variability then depends on whether biomass varies more or less in dominant species than in other species. Diversity was smaller in restored than remnant prairies partly because restored prairies were strongly dominated by the $\mathrm{C}_{4}$ grass $S$. scoparium. Because biomass was more stable in S. scoparium than in other species, lower $\mathrm{E}$ and diversity in restored prairies actually reduced inter-annual variability in community biomass.

Species effects on stability also were evident in between-location differences in summed covariances. Stability is increased when species respond differently to fluctuations and covariance in species' responses is negative (Ives et al. 2000). The prairies we studied were dominated by few species, so the sum of species covariances depended mainly on covariances among dominants. Summed covariances differed between locations partly because interannual change in biomass of two species that were abundant at Temple but rare at Riesel correlated negatively with change in biomass of other abundant species.

It could be argued that differences between prairie types in species composition, environmental conditions, or other variables obscured a positive effect of diversity on stability. For at least two reasons, we contend that diversity differed sufficiently between remnant and restored prairies to influence stability. First, the species pool in restored prairies was largely a subset of that of the paired remnant prairie. Restored and remnant prairies at each location thus were dominated by a similar group of perennial grasses and exhibited similar levels of production and, because of their proximity, were located on similar soils and experienced very similar precipitation regimes. Second, the diversity effect on stability often is assumed to be largely independent of species composition. In experimental plots to which species were randomly-assigned, temporal stability of plant production increased as $S$ increased (Tilman et al. 2006). In our study, diversity differed sufficiently between prairie types to have influenced stability. The diversity effect simply was constrained by dynamics of a dominant species (Wardle et al. 1997, Lepš 2004).

Our results do not imply that $\mathrm{E}$ and $\mathrm{S}$ are irrelevant to community stability. Indeed, results from studies in natural or semi-natural vegetation (Frank and McNaughton 1991, Dodd et al. 1994, Kahmen et al. 2005) and along experimental diversity gradients (Caldeira et al. 2005, Tilman et al. 2006) support the concept that diversity may stabilize function. However, dominant species have a disproportionate influence on the dynamics of community properties. Consequently, aggregate properties may vary widely in uneven communities depending on stability of dominant species, as is evident in responses of compositional stability to disturbances in savanna grasslands (Sankaran and McNaughton 1999), of bacterial densities to functional group richness in microbial microcosms (Naeem and $\mathrm{Li}$ 1997), and of aboveground biomass to annual variation in weather in synthesized grasslands (Pfisterer et al. 2004). The variance-mean scaling coefficient was similar among dominant and sub-dominant species other than S. scoparium. Had growth of this dominant grass been severely restricted by some perturbation, such as an extreme weather event or the outbreak of a speciesspecific disease, stability likely would have been greater in the more-diverse remnant than restored prairies.

Our results are consistent with Grime's (1998) massratio hypothesis, which holds that ecosystem properties 
are largely controlled by traits of dominant species, and with the conclusion of Hooper and Vitousek (1997) that ecosystem processes depend at least as much on functional properties of component species as on the number of species. Species identity matters because species differ in traits that link the response of biomass production to fluctuations in environmental and other factors. It is noteworthy that in our experiment biomass varied less in $S$. scoparium than in other dominant and co-dominant $\mathrm{C}_{4}$ grasses, including $P$. virgatum and $S$. nutans. Clearly, we require a greater understanding of the link between plant traits and stability of biomass production if we are to predict consequences of changing abundances or identities of dominant species for ecosystem properties (McGill et al. 2006).

Acknowledgements - We are indebted to Bob and Mickey Burleson and to Paul and Virginia Mezynski for permitting us to sample their prairies. Katherine Jones, Kyle Tiner, Chris Kolodziejczyk, Alicia Naranjo, Brett Boeselt, Doug Psencik and Brad Vaculin assisted with field work and separated plant material by species. Leanne Martin and Patricia Mielnick provided helpful reviews of the manuscript.

\section{References}

Caldeira, M. C. et al. 2005. Species richness, temporal variability and resistance of biomass production in a Mediterranean grassland. - Oikos 110: 115-123.

Cottingham, K. L. et al. 2001. Biodiversity may regulate the temporal variability of ecological systems. - Ecol. Lett. 4: 72-85.

Diamond, D. D. and Smeins, F. E. 1993. The native plant communities of the Blackland Prairie. - In: Sharpless, M. R. and Yelderman, Y. C. (eds), The Texas Blackland Prairie: land, history, and culture. Baylor Univ., pp. 6681.

Doak, D. F. et al. 1998. The statistical inevitability of stability-diversity relationships in community ecology. - Am. Nat. 151: 264-276.

Dodd, M. E. et al. 1994. Stability in the plant communities of the Park Grass Experiment: the relationships between species richness, soil $\mathrm{pH}$, and biomass variability. - Philos. Trans. R. Soc. Lond. B 346: 185-193.

Frank, D. A. and McNaughton, S. J. 1991. Stability increases with diversity in plant communities: empirical evidence from the 1988 Yellowstone drought. - Oikos 62: 360 362.

Grime, J. P. 1998. Benefits of plant diversity in ecosystems: immediate, filter and founder effects. - J. Ecol. 86: 902910.

Hooper, D. U. and Vitousek, P. M. 1997. The effects of plant composition and diversity on ecosystem processes. - Science 277: 1302-1305.

Huston, M. A. 1997. Hidden treatments in ecological experiments: re-evaluating the ecosystem function of biodiversity. - Oecologia 110: 449-460.
Ives, A. R. et al. 2000. Stability and species richness in complex communities. - Ecol. Lett. 3: 399-411.

Kahmen, A. et al. 2005. Diversity-dependent productivity in semi-natural grassland following climate perturbations. - Funct. Ecol. 19: 594-601.

Lepš, J. 2004. Variability in population and community biomass in a grassland community affected by environmental productivity and diversity. - Oikos 107: 64-71.

McArdle, B. H. et al. 1990. Variation in the size of animal populations: patterns, problems and artefacts. - J. Anim. Ecol. 59: 439-454.

McGill, B. J. et al. 2006. Rebuilding community ecology from functional traits. - Trends Ecol. Evol. 21: 178-185.

McNaughton, S. J. 1977. Diversity and stability of ecological communities: a comment on the role of empiricism in ecology. - Am. Nat. 111: 515-525.

McNaughton, S. J. 1985. Ecology of a grazing ecosystem: the Serengeti. - Ecol. Monogr. 55: 259-294.

Naeem, S. and Li, S. 1997. Biodiversity enhances ecosystem reliability. - Nature 390: 507-509.

Parry, S. et al. 2000. Particulate organic matter as a source of variation in denitrification in clods of soil. - Euro. J. Soil Sci. 51: 271-281.

Pfisterer, A. B. et al. 2004. Rapid decay of diversityproductivity relationships after invasion of experimental plant communities. - Basic Appl. Ecol. 5: 5-14.

Polley, H. W. et al. 2005. Patterns of plant species diversity in remnant and restored tallgrass prairies. - Restor. Ecol. 13: 480-487.

Polley, H. W. et al. 2006. Early-successional plants regulate grassland productivity and species composition: a removal experiment. - Oikos 113: 287-295.

Potter, K. N. and Derner, J. D. 2006. Soil carbon pools in central Texas: prairies, restored grasslands, and croplands. - J. Soil Water Conserv. 61: 124-128.

Sankaran, M. and McNaughton, S. J. 1999. Determinants of biodiversity regulate compositional stability of communities. - Nature 401: 691-693.

Schmid, B. et al. 2002. The design and analysis of biodiversity experiments. - In: Loreau, M. et al. (eds), Biodiversity and ecosystem functioning. Oxford Univ., pp. 61-75.

Smith, B. and Wilson, J. B. 1996. A consumer's guide to evenness indices. - Oikos 76: 70-82.

Sokal, R. P. and Rohlf, R. J. 1981. Biometry (2nd ed.). - Freeman.

Taylor, L. R. 1961. Aggregation, variance and the mean. - Nature 189: 732-735.

Tilman, D. 1996. Biodiversity: population vs ecosystem stability. - Ecology 77: 350-363.

Tilman, D. 1999. The ecological consequences of changes in biodiversity: a search for general principles. - Ecology 80: 1455-1474.

Tilman, D. et al. 2006. Biodiversity and ecosystem stability in a decade-long grassland experiment. - Nature 441: 629632.

Wardle, D. A. et al. 1997. The influence of island area on ecosystem properties. - Science 277: 1296-1299.

Weisberg, S. 1980. Applied linear regression. - Wiley.

Wilsey, B. J. and Polley, H. W. 2004. Realistically low species evenness does not alter grassland species-richness-productivity relationships. - Ecology 85: 2693-2700. 